This is a so-called personal version (author's manuscript as accepted for publishing after the review process but prior to final layout and copy editing) of the article.

Kowalkowski, C., Kindström, D., \& Gebauer, H. (2013), ' ICT as a Catalyst for Service Business Orientation ', Journal of Business \& Industrial Marketing, Vol. 28, Issue 6.

Readers are kindly asked to use the official publication in references.

\title{
ICT as a catalyst for service business orientation
}

\author{
Christian Kowalkowski ${ }^{\mathrm{a}}$ * \\ Daniel Kindström ${ }^{\mathrm{b}}$ \\ Heiko Gebauer ${ }^{\mathrm{c}}$
}

${ }^{a}$ Department of Marketing, CERS - Centre for Relationship Marketing and Service Management, Hanken School of Economics, Helsinki, Finland

and

Department of Management and Engineering, Linköping University, Linköping, Sweden

${ }^{\mathrm{b}}$ Department of Management and Engineering, Linköping University, Linköping, Sweden

${ }^{\mathrm{c}}$ Innovation Research in Utility Sectors (Cirus) at the Eawag: Swiss Federal Institute of Aquatic Science and Technology, Switzerland

*Corresponding author. christian.kowalkowski@hanken.fi, tel: +358 403521457 


\begin{abstract}
:
Purpose - Information and communication technology (ICT) is a key enabler for new productand process-oriented services. The article investigates how ICT can enable service differentiation and in doing so act as a catalyst for a service business orientation.

Design/methodology/approach - A qualitative, multi-case research design with eight multinational goods manufacturers.
\end{abstract}

Findings -Two distinct types of service-oriented differentiation are identified; services in support of the product (SSP), and services in support of the client's actions (SSC). The study finds that SSC have the largest positive impact on firms' service business orientation.

Research limitations/implications - Western firms in a limited sample of industries are studied. Furthermore, the service business orientation construct does not include any measurements of service profitability or impact on overall competitive advantage.

Practical implications - To various extend, successful firms are likely to pursue both SSP and SSC differentiation traits through ICT. The two options are interdependent and the framework presented helps managers to understand both key specificities and their interrelatedness.

Originality/value - The study contributes to theory on service strategies by specifically focusing on the enabling role of ICT for new services and its effects on each of the three dimensions of the service business orientation construct.

Paper type Research paper

Keywords: Industrial services, ICT, service business orientation, service orientation, differentiation, servitization 


\section{Introduction}

Increasingly, new information and communication technology (ICT) makes value creation based more on gathering and using informational content and less on tangible benefits. Rust (2004, p. 24) argues that, essentially, "the service revolution and the information revolution are two sides of the same coin". One manifestation of this so-called service revolution is that, in the past few decades, leading firms across industries have added services to their existing product offerings in order to increase differentiation and to maintain competitive advantage (Fang et al., 2008;

Gebauer and Kowalkowski, 2012; Raddats, 2011; Robinson et al., 2002). These services can be geared towards increasing the efficacy of the supplied product, i.e., services in support of the supplier's product (SSP), as well as being directed at the customer's business processes, i.e., services in support of the customer's action (SSC) (Mathieu, 2001a). In this 'servitization' process, ICT often plays a key role as enabler for a product-service transition (Neu and Brown, 2005; Penttinen and Palmer, 2007; Shepherd and Ahmed, 2000). Not only firms in the IT sector, such as IBM, but also manufacturers, such as Rolls-Royce and SKF, utilize ICT to add services to their existing offerings in order to create value and achieve sustainable competitive advantage. In their analysis of the servitization of manufacturers, Penttinen and Palmer (2007) show that ICT both enables deeper relationships with customers and more extensive service offerings, such as integrated solutions. That is, manufacturers use ICT to pursue a differentiation strategy through services.

An increased emphasis on services implies an increased service orientation of the business strategy. In line with Homburg et al. (2002a; 2002b), service business orientation (SBO) can be defined in terms of three dimensions: $i$ ) the number of services offered, ii) the number of customers to whom the services are offered, and iii) the emphasis placed on the services. These 
three dimensions are positive associated with the SBO of the firm. Previous research on servitization has dealt with issues such as the transition process (Mathieu 2001b; Matthyssens and Vandenbempt 2008; Penttinen and Palmer 2007), service strategies (Gebauer 2008; Kowalkowski et al., 2012; Kumar and Markeset 2007), and organizational arrangements (Davies et al. 2007; Gebauer and Kowalkowski 2012; Neu and Brown 2005). However, prior studies have not specifically focused on the role of ICT as an enabler for new services and on its impact on the firms' service business orientation. Few noteworthy exceptions are Matthyssens and Vandenbempt's (1998) study on creating competitive advantage in industrial services, Froehle et al.'s (2000) examination of strategic operations choices for new service development effectiveness and Homburg et al.'s (2002a) study on antecedents for implementing service strategies.

Against this background, the objective of this study is to investigate how ICT can enable service differentiation and in doing so act as a catalyst for a service business orientation. We use industrial services and service orientation theory (e.g., Antioco et al., 2008; Homburg et al., 2002b; Mathieu, 2001a) to formulate a theoretical framework for analyzing the impact of ICT on service business orientation. Case examples from multinational manufacturers are presented. These firms have utilized ICT to develop new services and enhance competitive advantage, attempting to differentiate their offerings based on non-price factors. The theoretical framework is linked to case data and effects on the firms' service business orientation are examined. Our results indicate that ICT can positively influence the service business orientation of manufacturers but that the effects are contingent on the type of services (i.e., SSP or SSC) offered. 


\section{Theoretical framework}

\subsection{Information and communication technology as service enabler}

In order to successfully compete in increasingly complex markets, the ability to use ICT for services is a key resource (Neu and Brown, 2005). Matthyssens and Vandenbempt (1998) argue that ICT is an important asset for creating superior customer value based on explicit service quality, proactive and integrated solutions as well as timely, empathic design of new services. According to previous research, new services can be introduced more rapidly into the market when having a significantly better control over the IT infrastructure (Froehle et al., 2000; Menor et al., 1998). Controlling the IT infrastructure is necessary for building a service system and enhancing service quality excellence (Zeithaml and Bitner, 2000). Hence, ICT enables better service delivery and leads to improved cross-functional communication and service-oriented business strategies (Antioco, 2006).

Furthermore, ICT enable firms to both reduce the costs for providing services (i.e., internal efficiency) and increase service revenues by infusing higher value into the customers' valuecreating processes through new services (Anderson et al. 1997). For example, ICT can facilitate for firms dealing with high diversity of demand, and it can be a tool for information sharing and information gathering on product usage and customer needs (Jong and Vermeulen 2003). The collection and processing of real-time information about the condition and utilization of the installed base can in turn enable new services with a focus on value-in-use (Kowalkowski and Brehmer, 2008).

Because ICT is becoming rapidly commoditized and is not a differentiator by itself (Carr 2003), differentiation lies in the new practices enabled by ICT (Brown and Hagel 2003). Competitors can rather easily imitate activities, processes, or even single organizational elements. 
Productivity gains through the use of ICT are often perceived as being particularly easy to imitate or copy. However, as activities, processes, and elements start to reinforce each other and begin to form more complex arrangements with more systemic characteristics, it immediately becomes much harder for competitors draw benefits from imitation (Miller and Friesen 1984; Mintzberg 1978; Porter 1996). ICT development and implementation can be coupled to other changes, such as redesigning service processes, deepen customer relationships or launching new services (Kowalkowski and Brehmer, 2008; Normann, 2001).

Since, ICT can have an enabling impact on firms' servitization (Matthyssen and Vandenbempt, 1998; Penttinen and Palmer, 2007), the influence on firms' service business orientation should be positive. This is because the number of services offered, service customers, and possibly the emphasis placed on services increase. While prior research has examined ICT development, service strategies, and service transition, we claim that additional insight is needed into how ICT influence firms' service business orientation. First, there is a need to further investigate the effect of ICT on the service options, here operationalized as effect on SSP or SSC. Despite the central role of ICT for successful servitization, this relationship seems to be neglected by literature. Second, the link between types of industrial services and service business orientation has not been studied sufficiently, Antioco et al. (2008) being an exception. In order to explore these relationships, the use of ICT to increase competitive advantage though service differentiation is analyzed.

\subsection{Differentiation through services - a classification}

An important distinction can be made between SSP - services which support the firm's product, for example maintenance, repair, and other after-sales services - and SSC - services in support of the customer's action in relation to the firm's product, such as a customer training or consultancy 
services (Antioco et al., 2008; Mathieu, 2001a; Ulaga and Reinartz, 2011). The main goal of SSP is to ensure the installation, use, and brokering of the product and/or to facilitate the customer's access to the product. In contrast, the main goal of SSC is not just to ensure product efficacy, but to help the customer maximize all the different business and production processes, actions, and strategies associated with the product. Hence, whereas SSP are inherently product-oriented, SSC are process-oriented. Therefore, differentiation through SSC requires competences other than through traditional SSP; the provider needs to have knowledge about how the product affects the customer's processes and how these processes can be improved. Mathieu (2001b) views SSC as "service as a product", which means that the customer may experience the service without buying the firm's product. Firms that opt for competing mainly though SSP are likely to have the product in the center of their value proposition, whereas SSC are inherently customer oriented and possible to offer independent of the product. ICT can be a key enabler both for deeper customer relationships and more extensive service offerings and product-service combinations (Penttinen and Palmer, 2007), which means that technology can have a central role for both SSP and SSC differentiation.

The two types of services can be compared on four main dimensions: the direct recipient of the service, the intensity of the relationship, the degree of customization of the service, and the predominant marketing variables (see Table 1). For SSP, the direct recipient of the service is the product, whereas it is a person within the customer organization in the case of SSC. The intensity of the relationship in terms of the potential number of employees and departments involved and the degree of collaboration, commitment, and trust, is low for SSP compared to SSC (Oliva and Kallenberg, 2003; Ulaga and Reinartz 2011). Furthermore, SSP are standardized to a high extent (i.e. low customization), whereas SSC are highly customized. Finally, the predominant marketing 
variables for SSP are physical evidence - the tangible products and equipment that facilitate service performance - and the process - an accurate and cost-efficient flow of service activities. For SSC, on the other hand, the predominant marketing variable is people, which includes both the provider's and the customer's personnel (Mathieu, 2001a).

\section{Insert Table 1}

\subsection{Service business orientation}

Firms can increase their service business orientation by focusing on SSP, SSC or a combination of the two (Antioco et al., 2008). Irrespective of focus, however, SBO can be defined as "an organization-wide embracement of a basic set of relatively enduring organizational policies, practices, and procedures intended to support and reward service-giving behaviors that create and deliver services excellence" (Lytle et al., 1998, p. 459). It is operationalized as a construct consisting of three interrelated, yet different dimensions (Homburg et al., 2002a; 2002b):

i) the number of services offered,

ii) the number of customers to whom the services are offered, and

iii) the emphasis placed on the services.

Hence, no dimension alone represents the SBO construct. In order to fully capture the construct, all three are needed, which means that firms must consider all of them when making strategic decisions about their service business (Homburg et al., 2002b).

The first criterion for SBO is to offer services; a firm offering few or no services cannot be service oriented. Hence, other things being equal, the more services a firm offers, the higher SBO 
it is considered to have (Homburg et al., 2002b). In line with Anderson et al. (2007), managers need to analyze their service portfolio and decide which existing services to offer (either as standard or option), which existing services not to offer, and which new services to develop. Second, the firm must decide to what customers it should offer services. For example, granting the largest customers special treatment through key account management means that these customers can be offered unique services (Brehmer and Rehme, 2009). However, if only a limited group of customers are offered services it does not reflect a high SBO. Other things being equal, the more customers that are offered services, the higher the SBO (Homburg et al., 2002b). Finally, in order to have a high SBO, the firm must also emphasize its services; that is, actively offer services to its customers. Compared to the number of services offered, the emphasis on services reflects a deliberate, proactive choice and, thus, more strongly indicates a shift from product to service orientation (Homburg et al., 2003). In business practice, manufacturers have tended to market and sell services not systematically but rather do this in a reactive manner only when some customers explicitly called for them (Kindström and Kowalkowski, 2009; Kowalkowski et al., 2012). Consequently, these firms have placed a low emphasis on services, which means that they have not had a high SBO. Other things being equal, the more actively the firm emphasizes its services, the higher its SBO.

\section{Methodology}

Due to the systemic and multidimensional characteristics of SBO and effects of ICT, we chose a qualitative case study approach to answer the question of how ICT can act as a catalyst for service business orientation (Edmondson and McManus, 2007). Empirical data comes from eight multinational, capital equipment manufacturers of Swedish and Swiss origin. The firms operate in a wide variety of industries, such as automation solutions, buses, cutting tools, outdoor power 
equipment, professional laundry systems, pumps, and warehouse trucks. Common denominators for the chosen firms are the product commoditization trend, which makes service differentiation a key strategic option, and the increasing use of ICT as an enabler for new services.

Firms were chosen that met four primary criteria: $i$ ) the firm is an industry market leader, ii) the firm pursues differentiation strategies, iii) the firm uses ICT to increase competitive advantage though services, and $i v$ ) access to key informants was provided. For each case, we sought to triangulate by using interview data, focus group data, and archival data such as internal reports and secondary articles as data sources. We used highly knowledgeable informants from different departments, groups, and hierarchical levels, as well as customers. A majority of the informants were central and local service managers, application specialists, and managing directors. The interview questions were open-ended and allowed the respondents to formulate their answers using their own words. Inter-firm focus group discussions with, and between, the managers were perceived as being very sincere and constructive since most of the managers were in similar positions within their organizations and none of the businesses they represented were competitors. The sampling process ceased at saturation, as connoted by information redundancy.

The data analysis was an iterative process matching theory and reality, where advantage of the systematic combining of both the empirical world and the theoretical models was taken. Dubois and Gadde (2002) label this process 'abductive' and it can be characterized as going back and forth between the data and the theory, creating fruitful cross-fertilization. In order to strengthen theory triangulation, we used different bodies of literature (mainly industrial marketing, service management and marketing, and strategic management theory) as means to interpret the findings. As recommended by Gibbert et al. (2008), key informants reviewed the interview transcripts and peers made a review of a draft version. Detailed case study write-ups for 
each firm and analysis of within-case data were made initially in order to identify case specific patterns. Respondents from each firm also received the write-ups and although they agreed with the overall structure and content, some respondents suggested slight changes, which were incorporated in the revised versions. A case study protocol was used and a case study database with all available interview transcripts, case study write-ups, and other documents was put together in order to increase reliability. Next, a cross-case comparison was made. Data was grouped into similar themes based on the research constructs and theoretical framework, and regrouped following the systematic combining process. Using Piekkari et al.'s (2010) terminology, these practices to enhance validity and reliability can be considered mainly as 'best practice' (purposeful sampling, theory building, selection criteria for informants, etc.), with elements of 'common' practice (mainly exploratory, interview-based studies, etc.) and 'innovative' practice (an abductive approach) in case research.

\section{Findings: ICT-enabled services and service business orientation}

In this section, we start by illustrating two traits of how manufacturers utilize ICT to compete through SSP and SSC. We describe how ICT has enabled service development and the effects of ICT-based service differentiation on SBO. Next, we analyze the effects of ICT on service differentiation. Lastly, we link the service differentiation options (i.e., SSP and SSC) to SBO, thereby exploring effects of ICT-based services on SBO (Matthyssens and Vandenbempt, 2008). 


\subsection{The case illustrations}

\section{Case illustration 1: internal efficiency and asset management}

Endress + Hauser is a leading supplier of measuring instruments and automation solutions for the industrial process engineering industry. Its first initiative on service business orientation was merely internal driven, although it eventually resulted in higher SBO in all three dimensions. The initiative focused on extending the use of their existing Enterprise Resource Planning (ERP) system from manufacturing to customer services. The intention was to improve internal efficiency of basic services such as calibration, repair and maintenance services. The essential goal of this ERP-system extension was to increase transparency and adequacy of information on the status of the installed measurement instruments currently used by customers.

The enhanced transparency and adequacy on information simplified internal planning processes for repair and maintenance services and increased the capacity utilization of the existing service resources. Service levels on mean-time-to-repair and mean-time-to-recover were improved, something that lead to an enhanced service quality perception by the customers. The enhanced quality of those basic SSP convinced more and more customers to outsource basic repair, calibration and maintenance activities. The increased transparency and adequacy of the information had also an interesting side effect. Providing this information to the customers implies that the firm has better control of their assets, or in other word of their investments in measurement instruments. Endress+Hauser turned this ERP solution into a web-based asset management system, where customers have the opportunity to use this information for their own processes. This information was deemed valuable for customers sticking to own maintenance departments or in case of necessary shutdowns of the industrial process equipment. 


\section{Case illustration 2: customer solutions and technical integration}

Toyota Material Handling Europe is a leading supplier of trucks and services, and part of the Toyota Group. The company operates through an in-house service organization on most markets, which is seen as a strategic advantage since most competitors operate through service partners. During the last decade in particular, service development has become more or less synonymous with ICT development.

Since 2002, the service organization is using a mobile business system and service technicians are using handheld computers to receive and report work orders and access customer fleet data and spare parts information. The system was implemented to improve internal efficiency by reducing administrative cost and increasing cash flow. The implementation exceeded expectations and also generated positive effects for the customers, such as faster and more reliable SSP processes and the possibility for customers to receive work reports electronically. More recently, the system has become a platform for new ICT-based solutions. The system collects data wirelessly from the machines and enables it to be analyzed over a web interface. In this way, value can be created by offering process analysis and consulting services. Customers can view the real-time utilization of their fleet and see how the trucks are driven, set driver access and shock levels remotely, and manage all production sites centrally. These services, which are primarily SSC, allow customers to reduce operating costs, improve safety, and increase productivity. Since most customers already purchase services from Toyota, the number of and the emphasis on new services are the SBO dimensions mainly affected. 


\subsection{Effects of ICT on SSP and SSC}

Analysis of the eight manufacturers confirms prior research that ICT refines and extends the firms' core business (Kraemer et al., 2000) and is used not only to create customer value through the integration of online applications and technical capabilities with business processes (Huizingh, 2002), but also internally with a focus on cost reductions and efficiency aspects. ICT can also enable an enhancement of customer-provider relationships by decreasing the cost of upholding the existing relationship and by expanding the broadness of the relationship through the inclusion of new services.

Historically, many service-related ICT initiatives have focused on lowering transaction costs and improving internal process efficiency (Kindström and Brege, 2008). For the case firms this has taken the form of utilizing ICT to reconfigure existing service processes, thereby improving the internal efficiency of offered services. Back-office processes in particular have been proven to be possible to automate or eliminate (Kowalkowski and Brehmer, 2008). In the most successful cases, the latter also has positive effects on the customer since automated order processes generally reduce costs for the customer as well. This can lead to changes in the service system design that in turn can lead to better process quality. An increased reliability of the service system may further increase process efficiency. Examples of mechanisms that affect efficiency include mobile devices for service employees, standardized, multinational information systems, direct billing, and transaction-efficient service order handling. Such initiatives involve relatively low risks, do not require a comprehensive understanding of the technology among top management, and the cost reductions allow a rather straightforward and measurable return on investment. 
As firms mature and become more comfortable with the use of ICT a shift in investment focus from primarily internal process efficiency to service differentiation can be discerned. This shift parallels the general servitization process and increasing service business orientation that takes place gradually in the manufacturers. Initially, SBO was low and more related to covering the costs for service provision than achieving differentiation though services; the cost coverage aimed at sustaining the product price premium. More recently, however, service differentiation has become more central for the competitiveness of the case firms. Together with the rapid development of ICT, this has spurred ICT-enabled service differentiation and, consequently, increased firms' SBO.

ICT has a substantial effect on the SSP option in establishing differentiated offerings, especially to new customers. This can be attributed to a traditional focus in most firms of emphasizing tangible features, for example based on what is technically possible to achieve. ICTbased SSP are often developed primarily in an inside-out manner that resembles conventional product development. That is, ICT is used to create new SSP from a perspective of what is technically possible and not necessarily what is needed and value creating from customers' point of view. However, many profitable SSP successfully extend and complement the existing offering portfolio, thereby enabling better service quality and product efficacy and subsequently lower customer costs. There is a wide range of generic SSP that are enabled and facilitated by ICT, for example remote monitoring and control, product utilization report packages, preventive maintenance agreements, and fleet management systems. As more and more information about product usage is possible to collect wireless in real time, firms have a more accurate foundation for proactive, higher-quality maintenance and operational services. 
In the SSC option, a multitude of activities regarding the strengthening of the customer relationships can be seen. This means that firms are not just creating new services but also addressing specific customer needs and processes, and use ICT as a vehicle for value creation by both relieving customers (i.e. reducing cost) and enabling customers' business (i.e. increasing

productivity) (Normann and Ramírez, 1994). ICT-based SSC can either be bundled with existing offerings or provided as stand-alone unbundled services to both existing and new customers. Furthermore, ICT enables the collection of real-time usage data, which is critical for the ability to offer advanced solutions, such as outcome-based contracts with dynamic pricing. Less extensive ICT-based SSC include technical consulting, process optimization, and customer training tools.

\subsection{Effects of ICT-based service differentiation on service business orientation}

The effects of ICT on SBO are seen to differ depending on which of the service differentiation options that are in focus. Furthermore, the effects also differ between the three dimensions constituting SBO; that is, the number of services, number of service customers, and emphasis of services.

ICT enables the development of new SSP but these are not necessarily new stand-alone services. For example, more detailed customer reports about their installed base may be offered in connection to existing service contracts rather than offered as a separate service. Customer benefits enabled by SSP, such as reduced operational costs through process automation, better predictability, and information on product performance and usage in customer operations, lead to more attractive value propositions. These new service customers have previously not found any reasons to buy services from their product suppliers. Instead, many customers have performed the services in-house or have purchased them from third-party service providers. As the SSP provided by the manufacturer become more competitive, however, more customers ask for them. 
This means that many ICT-based SSP lead to new service customers. However, since SSP are inherently geared towards the manufactured products, the manufacturer's service emphasis is generally lower compared to SSC. That is, managers view the firm's core offering to be the products, which are augmented with services supporting the product.

Regarding SSC, manufacturers are constantly finding new ICT-based services possible to offer. In terms of SBO, the challenge may rather be to find new service customers, as the marketing and selling of SSC requires more in-depth knowledge of the customers' operations compared to SSP sales. With some exceptions, such as basic training services, SSC generally require closer customer-supplier relationships (trust, commitment, adaptation, etc.) compared to SSP (Antioco et al., 2008). This means that not all product customers are prepared to buy SSC, thereby becoming 'service customers'. Neither are all customers necessarily offered all SSC. Large and strategic customers may receive special treatment and be offered customized services that, in fact, may be co-developed together with particular customers, and therefore not offered to a wider set of customers. Furthermore, in line with the service transition analogy, many customers buy SSP before buying SSC. This means that many of the potential customers of new, ICT-based SSC are already service customers since they buy SSP (and also products) from the firm. Nevertheless, manufacturers have the possibility to offer SSC to customers other than the ones buying products and SSP (Mathieu, 2001a), although our sample shows that this seldom is the case in practice. Therefore, the impact on the new customer dimension of SBO is lower for SSC than for SSP.

Finally, the service emphasis is stronger for SSC than SSP and many manufacturers use ICT-based SSC to promote their espoused strategy to become more service oriented, or even to claim (whether true or not) that they already perceive themselves to be service providers 
primarily. This study corroborates the findings in Homburg et al.'s (2003) quantitative study of service-oriented strategy in manufacturers that emphasis on services has a larger impact on SBO than the number of services offered. That is, firms need to actively market and sell their services to their customers. Taken together, as illustrated in Table 2, SSC have the largest positive impact on manufacturers' service business orientation.

Insert Table 2

\section{Implications}

\subsection{Implications for theory}

This study identifies effects of ICT-based service differentiation on service business orientation and highlights the key role that ICT has for the competitive advantage of manufacturers. Prior research has recognized ICT as a key enabler for new service processes and offerings but not explicitly studied its role and impact on the business. Linking effects of ICT to each dimension of the service business orientation construct extends existing theory, making a contribution to service management research in the context of servitization in manufacturers. In so doing, the study complements existing research on service differentiation (e.g., Gebauer, 2008; Mathieu, 2001b; Matthyssens and Vandenbempt, 2008; Robinson et al., 2002) and service business orientation (e.g., Antioco et al., 2008; Gebauer et al., 2010; Homburg et al., 2002b).

Furthermore, in line with Treacy and Wiersma's (1995) argument that firms can excel in more than one value discipline, this study shows that firms, to various extents, pursue both service differentiation options (i.e., SSP and SSC) through ICT. The two strategic service options 
are highly interrelated and can provide positive feedback loops to each other. This means that synergies seem to be more common than non-synergic effects between the two. For example, internal ICT investments that result in increased service process efficiency may be prerequisites for developing and delivering competitive SSP and SSC. Furthermore, a tailored solution provided to one customer can to a certain degree be standardized and selected elements can be unbundled and launched as new services that are offered also to the wider range of customers. Taken together, this makes it difficult to separate and isolate single effects of ICT on SBO since ICT-based services can effect both differentiation options simultaneously.

\subsection{Limitations and future research directions}

Being qualitative, this study does not offer any quantification of the effects of ICT-based service differentiation on the service business orientation of manufacturers, which is a limitation.

Therefore, combining qualitative and quantitative research methodologies could help quantifying the complex relationships between the ICT-based service differentiation and SBO constructs. Furthermore, since the SBO construct, as defined by Homburg et al. (2002a; 2002b), does not include any measurements of 'success', such as service profitability or the impact of services on overall competitive advantage, future research should also take this dimension into account. Since the study is context-bound, its analytical generalizations hold only in the context of highvolume manufacturers in B2B settings. Since the empirical data comes from multinational firms based in Europe, contrasting this study with studies on other industries and countries can test the transferability of our findings.

\subsection{Implications for practice}

For managers, our study shows effects of ICT-based service differentiation on service business orientation. ICT is quickly becoming commoditized and the rapid technological development 
means that ICT neither is a differentiator by itself nor a key constraint for new offerings. Rather, the challenge is often to keep pace with the technological development and the emerging opportunities that arise, while maintaining internal alignment and linking technological possibilities with expressed and latent customer needs. Even if ICT-based services have the potential to enhance provider as well as customer competitiveness, this value can be difficult to realize in practice. Many promising services founder on, among other things, managers underestimating the challenges associated with large-scale implementation projects and the obstacles faced by technology-centered manufacturers in fully understanding the complex business needs and actual user needs of potential customers (Flowers, 1996; Brady and Davies, 2010). Therefore, managers should have in mind that a strategic move to increase SBO through investments in ICT requires a business rationale and strategic congruence as well as the critical resources and capabilities needed.

In order to increase the SBO of the firm, top management support to increase the emphasis on services is particularly important. Although ICT-based SSC have the largest positive impact on firms' service business orientation, managers must be aware of the fact that an increased emphasis of the firm's SSC business generally involves a more top-to-bottom change and implies a more difficult strategic move than a focus on SSP. In reality, successful firms are likely to pursue both service differentiation options to various degrees.

\section{References}

Anderson, E. W., Fornell, C., \& Rust, R. T. (1997). Customer Satisfaction, Productivity and Profitability: Differences between Goods and Services. Marketing Science, 16(2), 129145. 
Anderson, J. C., Kumar, N., \& Narus, J. A. (2007). Value Merchants: Demonstrating and documenting superior value in business markets. Boston, MA: Harvard Business School Press.

Antioco, M. (2006). Service Orientations of Manufacturing Companies: Impact on New Product Success. Unpublished PhD Dissertation, Technische Universiteit Eindhoven, Eindhoven.

Antioco, M., Moenaert, R. K., Lindgreen, A., \& Wetzels, M. G. M. (2008). Organizational antecedents to and consequences of service business orientations in manufacturing companies. Journal of the Academy of Marketing Science, 36(3), 337-358.

Brady, T. and Davies, A. (2010), " From hero to hubris - reconsidering the project management of Heathrow's Terminal 5", International Journal of Project Management, Vol. 28 No. 2, pp. 151-57.

Brehmer, P.O., \& Rehme, J. (2009). Proactive and reactive: drivers for key account management programmes. European Journal of Marketing, 43(7-8), 961-984.

Brown, J. S., \& Hagel, J. (2003). Does IT matter? Harvard Business Review, 81(7), 109-112.

Carr, N. G. (2003). IT doesn't matter. Harvard Business Review, 81(5), 41-49.

Davies, A., Brady, T., \& Hobday, M. (2007). Organizing for solutions: systems seller vs. systems integrator. Industrial Marketing Management, 36(2), 183-193.

Dubois, A., \& Gadde, L.-E. (2002). Systematic combining: an abductive approach to case research. Journal of Business Research, 55(7), 553-560.

Edmondson, A. C., \& McManus, S. E. (2007). Methodological fit in management field research. Academy of Management Review, 32(4), 1155-1179.

Flowers, S. (1996), Software Failure: Management Failure. John Wiley and Sons, Chichester, UK. 
Froehle, C. M., Roth, A. V., Chase, R. B., \& Voss, C. A. (2000). Antecedents of new service development effectiveness: An exploratory examination of strategic operations choices. Journal of Service Research, 3(1), 3-17.

Gebauer, H. (2008). Identifying service strategies in product manufacturing companies by exploring environment-strategy configurations. Industrial Marketing Management, 37(3), 278-291.

Gebauer, H., Edvardsson, B., \& Bjurklo, M. (2010). The impact of service orientation in corporate culture on business performance in manufacturing companies. Journal of Service Management, 21(2), 237-259.

Gebauer, H., \& Kowalkowski, C. (2012). Customer-focused and service-focused orientation in organizational structures. Journal of Business \& Industrial Marketing 27(7), 527-537.

Gibbert, M., Ruigrok, W., \& Wicki, B. (2008). What passes as a rigorous case study? Strategic Management Journal, 29(13), 1465-1474.

Homburg, C., Fassnacht, M., \& Guenther, C. (2003). The role of soft factors in implementing a service-oriented strategy in industrial marketing companies. Journal of Business-toBusiness Marketing, 10(2), 23-51.

Homburg, C., Hoyer, W. D., \& Fassnacht, M. (2002). Service orientation of a retailer's business strategy: dimensions, antecedents, and performance outcomes. Journal of Marketing, 66(4), 86-101.

Homburg, C., M., F., \& Günther, C. (2002). Erfolgreiche umsetzung dienstleistungsorientierter strategien von industrieunternehmen. Schmalenbachs Zeitschrift für betriebswirtschaftliche Forschung, 54(9), 487-508.

Huizingh, E (2002), Towards successful e-business strategies: a hierarchy of three management models, Journal of Marketing Management, 18,721-747. 
Jong, J. P. J., \& Vermeulen, P. A. M. (2003). Organizing successful new service development: a literature review. Management Decision, 41(9), 844-858.

Kindström, D., \& Brege, S. (2008). The next step for e-business among mature and established companies: a focus on revenue and differentiation instead of costs. International Journal of Electronic Business, 6(5), 462-475.

Kindström, D., \& Kowalkowski, C. (2009). Development of industrial service offerings: a process framework. Journal of Service Management, 20(2), 156-172.

Kowalkowski, C., \& Brehmer, P.O. (2008). Technology as a driver for changing customerprovider interfaces: evidence from industrial service production. Management Research News, 31(10), 746-757.

Kowalkowski, C., Kindström, D., Brashear Alejandro, T., Brege, S., \& Biggemann, S. (2012). Service infusion as agile incrementalism in action. Journal of Business Research, 65, 765772.

Kraemer, K, Dedrick, J and Yamashiro, S (2000), Refining and extending the business model with information technology: Dell Computer Corporation, The Information Society, 16, 521.

Kumar, R., \& Markeset, T. (2007). Development of performance-based service strategies for the oil and gas industry: a case study. Journal of Business \& Industrial Marketing, 22(4), 272-280.

Lytle, R. S., Hom, P. W., \& Mokwa, M. P. (1998). SERV*OR: A Managerial Measure of Organizational Service-Orientation. Journal of Retailing, 74(4), 455-489.

Mathieu, V. (2001a). Product services: from a service supporting the product to a service supporting the client. Journal of Business \& Industrial Marketing, 16(1), 39-61. 
Mathieu, V. (2001b). Service strategies within the manufacturing sector: benefits, costs and partnership. International Journal of Service Industry Management, 12(5), 451-475.

Matthyssens, P., \& Vandenbempt, K. (1998). Creating competitive advantage in industrial services. Journal of Business \& Industrial Marketing, 13(4/5), 339-355.

Matthyssens, P., \& Vandenbempt, K. (2008). Moving from basic offerings to value-added solutions: Strategies, barriers and alignment. Industrial Marketing Management, 37(3), 316-328.

Menor, L. J., Roth, A. V., \& Mason, C. H. (1998). Agility in retail service management: a numerical taxonomy. Manufacturing and Service Operations Management, 3(4), 273-292.

Miller, D., \& Friesen, P. H. (1984). Organizations: A Quantum View. Englewood Cliffs, NJ: Prentice Hall.

Neu, W. A., \& Brown, S. W. (2005). Forming Successful Business-to-Business Services in Goods-Dominant Firms. Journal of Service Research, 8(1), 3-17.

Normann, R. (2001). Reframing Business - When the Map Changes the Landscape (First ed.). Chichester, UK: John Wiley \& Sons, Ltd.

Normann, R., \& Ramírez, R. (1994). Designing Interactive Strategy: From Value Chain to Value Constellation. Chichester, UK: John Wiley \& Sons.

Oliva, R., \& Kallenberg, R. (2003). Managing the transition from products to services. International Journal of Service Industry Management, 14(2), 160-172.

Penttinen, E., \& Palmer, J. (2007). Improving firm positioning through enhanced offerings and buyer-seller relationships. Industrial Marketing Management, 36(5), 552-564.

Piekkari, R., Plakoyiannaki, E., \& Welch, C. (2010). 'Good' case research in industrial marketing: Insights from research practice. Industrial Marketing Management, 39(1), 109-117. 
Raddats, C. (2011). Aligning industrial services with strategies and sources of market differentiation, Journal of Business \& Industrial Marketing, 26(5), 332-343.

Robinson, T., Clarke-Hill, C. M., \& Clarkson, R. (2002). Differentiation through service: A perspective from the commodity chemicals industry. The Service Industries Journal, 32(July), 149-166.

Rust, R. T. (2004). If Everything Is Service, Why Is This Happening Now, and What Difference Does It Make?: Invited Commentaries on "Evolving to a New Dominant Logic for Marketing". Journal of Marketing, 68(January), 23-24.

Shepherd, C., \& Ahmed, P. K. (2000). From product innovation to solutions innovation: a new paradigm for competitive advantage. European Journal of Innovation Management, 3(2), 100-106.

Treacy, M., \& Wiersema, F. (1995). The discipline of market leaders. Reading, MA: AddisonWesley.

Ulaga, W., \& Reinartz, W. J. (2011). Hybrid offerings: how manufacturing firms combine goods and services successfully. Journal of Marketing, 75(November), 5-23.

Zeithaml, V. A., \& Bitner, M.-J. (2000). Service marketing: Integrating customer focus across the firm. New York: McGraw-Hill. 
Table 1. A classification scheme for services (based on Mathieu (2001a, p. 40)).

\begin{tabular}{|c|c|c|}
\hline & SSP & SSC \\
\hline Direct recipient & Product & Person \\
\hline $\begin{array}{c}\text { Intensity of the } \\
\text { relationship }\end{array}$ & Low & High \\
\hline $\begin{array}{c}\text { Customization } \\
\text { Predominant } \\
\text { marketing variable }\end{array}$ & $\begin{array}{c}\text { Physical evidence } \\
\text { and process }\end{array}$ & People \\
\hline
\end{tabular}


Table 2. Effects of service differentiation through SSP and SSC on service business orientation.

\begin{tabular}{|l|l|l|}
\hline & SSP & SSC \\
\hline New services & Few & Many \\
\hline $\begin{array}{l}\text { New service } \\
\text { customers }\end{array}$ & High & Medium \\
\hline $\begin{array}{l}\text { Increased service } \\
\text { emphasis }\end{array}$ & Medium & High \\
\hline
\end{tabular}

